\title{
En medisinalinnberetning fra Troms 1812
}

\author{
Kunnskap om befolkningens helse er viktig for sentrale myndigheter. Fra 1803 var distrikts- \\ legene pålagt å sende inn en årlig medisinalrapport med svar på en rekke spørsmål. \\ Noen av de gamle rapportene er oppbevart i Riksarkivet i Oslo. Rapporten for 1812 \\ fra distriktskirurg Claus Jacob Monrad i Troms er transkribert og kommentert.
}

30.januarii 1813

Underdanig Indberetning!

Paa grund af det Høy. Kongelige Danske Cancellies Befaling dat. 20de. December 1803, har jeg herved den underdanig frihed paa de anførte Poster som er følgende, at meddele min underdanige Betonkning!

1. post. Udj det mig allernaadigst anfortroede Chirurgiat er for naervarende ingen smitsaam Sygdome iblandt Folket, naar undtages 8de Veneriske Personer, som blev i November Maaned d.A af mig taget under Kuur og Hoelbredet.

Smittens forkomst har udentvivl sin oprindelse fra Mandskabet paa et Russeskib, som afvigte Vinter paa Tromsøe laae Vinterleie.

2. post. Hvad Fødemidlerne angaar, da er Quanditeden der af iforhold til Folkemongden uforholdsmesig liden. For at drøye Brødet, bruges mange Surrogater s:s: hos de som haver Kornutsced, bruges tørret og malet Byghalm, Fisk og Fiskeben, Høimuule /:Rumox Crispus:/, Tørret og malet Birke-bark, en sort Bregne, her kaldet Telg eller Moldfoer, Arvegrces: Noelde, Blade af Nober og Rødkaal etc. Dette giver anledning til at Folket ikke haver leilighed at nyde saa meget som udfordres til Føde for Lagemet; saavelsom avlen af alle de omtalte Brød-Surrogater slettere vadsker, hvorved Sygdomme opstaa; og om ikke, da er Folket svakket, og udmarglet ${ }^{1}$, at de ved ellers ikke dødelige Sygdomme, blivet et offer for Døden.

Disforuden har dette Aar for dette District, varet ualmindelig ufrugtbaar. Intet Koren eller Havefrugter blev avlet, og Folket haver mistet deres Udsad, hvortil vor kolde og korte Sommer, og tidlige Nattekulde haver varet Aarsag.

3. post. Hvad Vaccinatinen angaar, da haver jeg i dette Aar ikke for bestandige Omreiser i Embeds Forretninger i dette mitt vidløftige District, haft leilighed at vaccinere mere end 11 Personer.
4. post. Hvad Mortaliteden betreffer, da overstiger de dødes Tal, meget de føtes.

5. post. Ikke er mig usedvanlige Jndtruffne Ulykkelige Hendelser bekiendt

6. post. Ingen examineret Giordemoder forefindes $i$ Tromsøe Fogderi.

7. post. At dette Fogderie mere end andre Stceder for Quaksalverie er bekiendt, er det ikke, men at nogen bevislig Klage over disse for utøvede skadelige Kurer kunde vare at andrage, er mig ikke bekiendt.

Mine som Lage her i Districtet brugende Medicamenter, erholder jeg deels fra Bergen, og deels fra Trondhiem.

Fra det første Stced til mit Hiemstced, regnes for at vare 180 Miile, og det sidste 70 Miile. Medicamenternes bonitet har jeg til denne Tiid ej fundet noget at klage over; men vad Priserne angaaer, da kan de af mig ej Bedømmes, da jeg er aldeles uvidende om de forskjillige procento tilloeg Apotekerne i de senere Aaringer ere Tilstaaede.

Hvilke af mig afgivne Betcenkninger og Besvarelses Efteretninger jeg herved har den Ere at tilstille Deres Høibaarenhed.

Karnoes den 31.de December 1812.

Underdanigst C. Monrad Districts Chirurg for Tromsøe Fogderie

Høibaaren Herr Amtmand Baron Wedel Jarlsberg

${ }^{1}$ Ud-mergle, v. efter ty. ausmergeln, udmarve, udpine (1) 
På 1600- og 1700-tallet ble befolkningstilveksten dempet av smittsomme sykdommer, og enevoldsstaten begynte så smått å reformere fattigstell og medisinalvesen. Mot slutten av 1700-tallet begynte staten å ta stadig mer ansvar for innbyggernes helse. Mellom 1780 og 1820 ble det opprettet 35 offentlige stillinger for leger og kirurger i norske distrikter (2).

20. desember 1803 gikk det ut et «Cancellie Circulaire», eller rundskriv, til amtmennene i Danmark og Norge. Her ble legene pålagt å innberette «alt, hvad det angaaer den offentlige Sundhedspleie» (3). Rundskrivet inneholdt en liste over hva legene særlig skulle innberette til Det Kongelige Sundhetscollegium (4), de såkalte medisinalberetninger. Sunnhetskollegiet lå i Danmark. I 1809 ble det på grunn av krigen opprettet et eget sunnhetskollegium for Norge. I 1807 hadde Danmark-Norge sluttet seg til Napoleons side. Det ble handelsblokade, matmangel, nød og fortvilelse. «Den fattige sulted, den rige led savn,» som Henrik Ibsen senere skrev i Terje Vigen. Medisinforsyningen sviktet også. I begynnelsen av 1808 sendte den midlertidige regjeringskommisjon for Norge et spørreskjema til landets apotekere og ba om å få opplyst det årlige forbruk av varer som måtte importeres det kommende år. Resultatet av undersøkelsen ble at man besluttet å opprette et medisinaldepot som skulle sikre tilførselen av medisiner i krisetider. Det fungerte til rundt 1820 .

Den foreliggende medisinalberetningen ble skrevet av distriktskirurg Claus Jacob Monrad (1768-1838). Han var fra Haderslev i Sønderjylland og kom til Karnes i Lyngen i 1793. Der ble han boende resten av livet. Senjen og Troms fogderi tilhørte Finnmark amt fra 1787 til 1865, da Tromsø amt ble opprettet.

\section{De enkelte postene}

I første post angir Monrad at den eneste smittsomme sykdommen han har hatt i distriktet er venerisk sykdom. Mot venerisk sykdom brukte man innsmøring med grå kvikksølvsalve eller kalomel innvortes. Urtekurer med sarsaparillerot, guajakved og kvassia ble også brukt. Distriktslegen er sikker på at smitten var kommet med et russisk skip. Russehandelen, pomorhandelen, hadde vokst frem på 1700-tallet til tross for sterke protester fra kjøpmennene i Bergen. Pomorhandelen var regulert og til tider forbudt, men ble frigitt i nødsårene. I perioden 1810-14 kom det 72 russeskuter til Tromsø (5).

Medisinalberetningen er skrevet i en periode som var kritisk for landet. I NordNorge var det misvekstår 1801-03, og det ble mange års feilslått fiske og lave fiskepriser. I 1812 var det uår over hele landet. Norge har «aldrig været i en så ulykkelig forfatning som i dette øjeblik og hastig hjælp må gives, hvis redning fra undergang endnu skal være mulig», skrev visestatt-

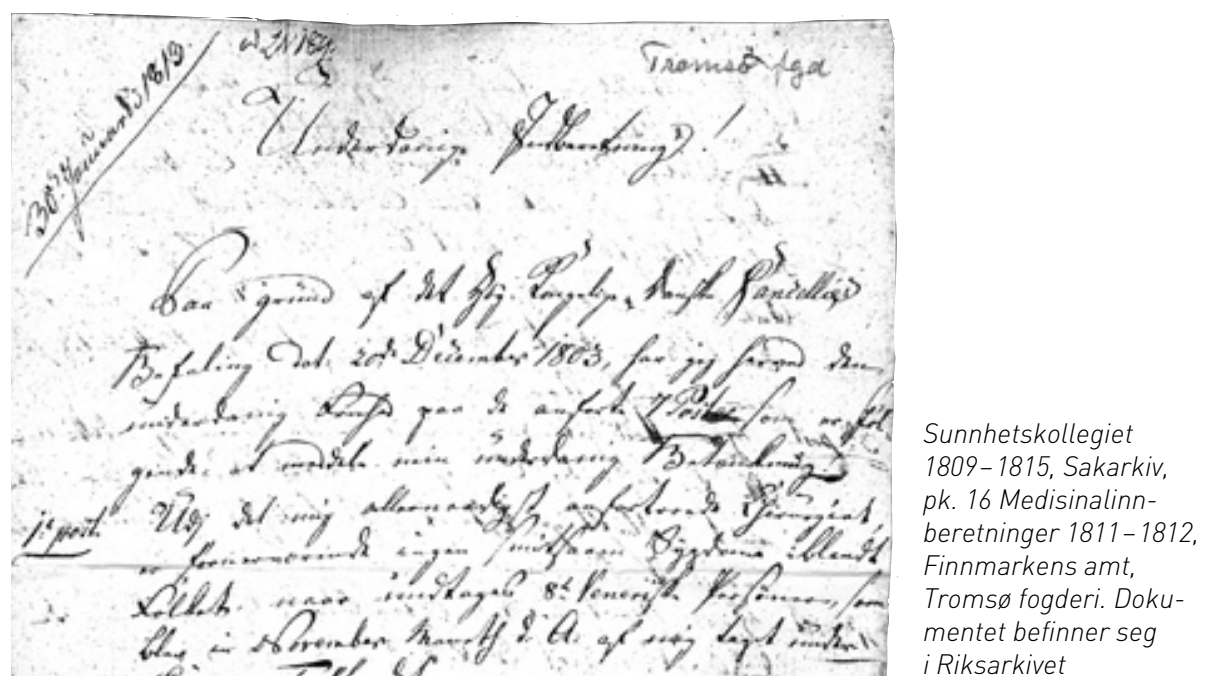

holder Frederik av Hessen fra Christiania 5. april 1813. Liknende rapporter kom fra flere steder i landet (6).

I tredje post skriver Monrad ganske utførlig om hvilke matsurrogater som ble brukt i Troms. Halmen var bl.a. brukt som underlag i sengene, men i knappe tider kunne de gi sengehalmen til kuene, eller, som Monrad anfører her, blande den i brødet (7). Frø av krushøymol eller Rumex crispus kunne, som her, blandes i brødmelet. Mer vanlig har det vært å bruke den nederste del av stengelen kokt som grøt (8). Ordet «barkebrødstider» er nesten synonymt med harde nødsår.

I Troms brukte de bjørkebark, da det var mangel på de tresorter som ble mest brukt til barkebrød i andre deler av landet, nemlig alm og furu. I Troms ble bregner mye brukt til mat for sau og krøtter, både bladene og de underjordiske delene (mollfôr). Arvegress eller vassarve (Stellaria media) kan brukes som spinat eller salat, det har en frisk smak (8). Nesle eller stornesle (Urtica diotica) var viktig i folkemedisinen og ble særlig brukt mot revmatiske lidelser og luftveissykdommer (8).

Monrad beklager at han ikke har fått vaksinert mer enn 11 personer fordi han har hatt så mye å gjøre på sine reiser. Det er koppevaksinen det her er snakk om. De store koppeepidemiene var allerede på retur da vaksinering ble lovfestet i 1810 (2). Før man fikk vaksinen med kukopper, kunne man innpode verkeblæreinnhold eller sårskorpe fra koppepasienter. Metoden var tidlig kjent i Kina og spredte seg via Tyrkia til Europa på 1700-tallet (9).

Ifølge kirkebøkene for Tromsø døde det 97 personer i 1812. Av disse var 20 under ett år, sju var i alderen 1-10 år, 11 var 10-20 år, det var 34 i aldersgruppen 20-50 år og bare 23 hadde nådd 50 års alder. Det året var det fødselsunderskudd - bare 80 fødsler ble registrert. I Lyngen var det et tilsvarende underskudd, med 60 døde og 38 fødte i 1812. Folketallet i Troms gikk tilbake hvert år fra 1810 til 1814 (5).
Monrad anfører at han ikke har noen jordmor med offentlig godkjent utdanning. Han nevner ikke Martha Tysse, som praktiserte som jordmor i Tromsø. Den første utdannede jordmoren kom til Tromsø i 1830-årene (10).

1812 var bare ett av flere nødsår i denne perioden. Totalt gikk folketallet i Troms ned fra ca. 19300 til ca. $17800(7,7 \%)$ fra 1801 til 1815 (11). På landsbasis var det en liten reduksjon i folketallet $\mathrm{i}$ årene 1813-14, fra 901580 til 899999 (0,2\%). Men dette kan sies å være den siste demografiske krisen i Norge - senere har det vært vekst i folketallet hvert eneste år.

\section{Gunvor Solheim}

gunsol@online.no

Wilh. Wilhelmsens vei 71

1362 Hosle

Jeg takker Anne Merete Ravnum Aas ved Riksarkivet for hjelp til transkripsjonen.

Oppgitte interessekonflikter: Ingen

\section{Litteratur}

1. Ordbog over det danske sprog (1700-1959). http://ordnet.dk/ods/opslag?id=582812 (4.5.2009)

2. Moseng $O G$. Ansvaret for undersåttenes helse 1603-1850. Oslo: Universitetsforlaget, 2003: 107.

Medisinalmeldingene 1804. Oslo: Helsetilsynet, 2004: 6.

4. Schønsby HP. The medicinal reports from the dis trict physicians - an indispensable source to the Norwegian medicinal past. Michael 2005; 3: 219.

5. Andresen A. Troms $\varnothing$ giennom 10000 år. Bd. 2. Tromsø: Tromsø kommune, 1994: 50

6. Mykland K. Norges historie. Bd. 2. Oslo: Cappelen 1978: 239-40

7. Høeg OA. Planter og tradisjon. Oslo: Universitetsforlaget, 1974: 26

8. Mehus H, Vorren B. Viltvoksende grønne matplanter i Nord-Norge. Ottar 1978; 16: 106-7.

9. Sverre N. Et studium av farmasiens historie. Oslo: Eget forlag, 1952: 89

10. Ytreberg NA. Troms $\varnothing$ bys historie. Bd. 1. Troms $\varnothing$ : Peder Norbye, 1946: 412.

11. Kristoffersen I. Troms. Oslo: Gyldendal, 1979: $184-5$.

Manuskriptet ble mottatt 21.1. 2009 og godkjent 7.5. 2009. Medisinsk redaktør Anne Kveim Lie. 